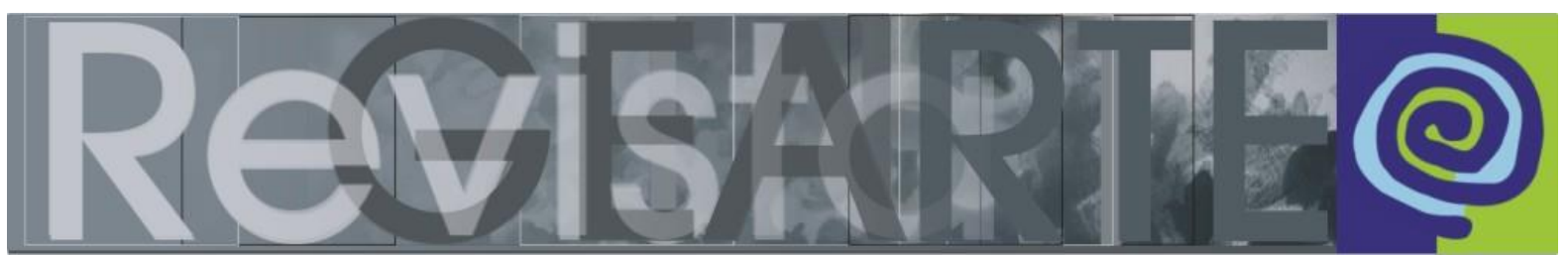

ISSN 2357-9854 | e-ISSN 2596-3198 (online)

\title{
A aventura do "espalha-brasa": arte na Pedagogia na Universidade Federal do Ceará
}

\author{
Luciane Germano Goldberg \\ (Universidade Federal do Ceará — UFC, Fortaleza/CE, Brasil)
}

\begin{abstract}
RESUMO - A aventura do "espalha-brasa": arte na Pedagogia na Universidade Federal do Ceará - Aborda práticas pedagógicas de arte e educação no curso de Pedagogia da Universidade Federal do Ceará. Serve-se da metáfora do "espalha-brasa", como referência ao brinquedo de parque diversões que tem cadeiras suspensas que giram no seu próprio eixo em alta velocidade, propondo pensar a arte na Pedagogia como uma experiência estética transformadora, mobilizadora e produtora de novas visões de mundo, sentidos e percepções. Partilha metodologias processuais, vivenciais, ativas e participativas, buscando promover liberdade, autonomia e horizontalidade das relações a partir de processo (auto)biográfico.
\end{abstract}

PALAVRAS-CHAVE

Arte na Pedagogia. Arte e Educação na UFC. Práticas Pedagógicas em Arte e Educação. Autobiografia.

ABSTRACT - The adventure of "Wave Swinger": art in Pedagogy at Universidade Federal do Ceará (UFC) - Addresses pedagogical practices of art and education in the Pedagogy course at Universidade Federal do Ceará. It uses the metaphor of "Wave Swinger", as a reference to the amusement park toy that has suspended chairs that rotate on its own axis at high speed, proposing to think of art in Pedagogy as an aesthetic experience that transforms, mobilizes and produces new worldviews, senses, and perceptions. It shares procedural, experiential, active and participatory methodologies, seeking to promote freedom, autonomy and horizontality in relationships from a (auto)biographical process.

\section{KEYWORDS}

Art in Pedagogy. Art and Education at UFC. Pedagogical Practices in Art and Education. Autobiography.

RESUMEN — La aventura de la "silla voladora": arte en Pedagogía en la Universidade Federal do Ceará (UFC) - Involucra prácticas pedagógicas de arte y educación en el curso de Pedagogía. Se sirve de la metáfora de la silla voladora, instalación de parques de atracciones que posee asientos suspendidos que giran rápidamente alrededor de su propio eje. Se propone pensar el arte en la Pedagogía como una experiencia estética transformadora, movilizadora y productora de nuevos puntos de vista, sentidos y percepciones. Se comparte metodologías procesuales, vivencias, activas y participativas, buscando promover la libertad, autonomía y horizontalidad de las relaciones a partir del proceso (auto)biográfico.

\section{PALABRAS-CLAVE}

Arte en la Pedagogía. Arte y Educación en la UFC. Prácticas Pedagógicas en Arte y Educación. Autobiografía. 


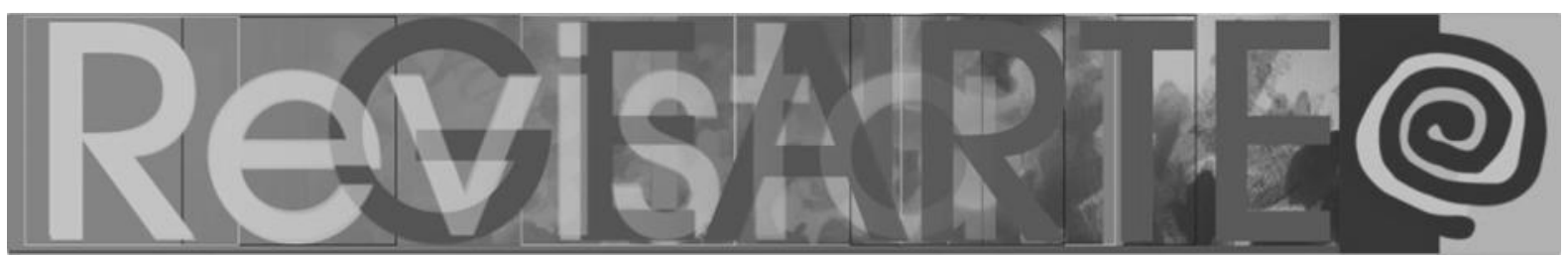

Dentro de cada criança, como dentro de cada "antiga criança", existem imensas virtualidades sensoriais, aptidões emotivas, possibilidades de "felicidades sensíveis". O educador que não faz tudo o que pode, "agora", no plano da educação escolar - que é o plano mais geral e decisivo - para exaltar essas virtualidades, que deixa passar o momento oportuno, quer por indiferença, por cansaço ou por negligência, contribui para manter a banalidade do mundo, a mediocridade do homem, a insignificância da vida. Bem entendido, tudo isto é condizente com uma ordem que está sendo mantida: nivelamento integrador, normalizações em todos os sentidos. Mas então, por que pretender que somos educadores? Em nome de que futuro humano? Em nome de que adiamento? Em nome de que desvio das razões de existir?

Jean-Claude Forquin (1973, p. 47-48).

Olá! Sou Luciane Goldberg, arte-educadora e professora de arte que, somando 20 anos de docência na área, partilharei aqui algumas das práticas, vivências, metodologias e conteúdos desenvolvidos na disciplina de Arte e Educação do Curso de Pedagogia da Faculdade de Educação da Universidade Federal do Ceará (FACED/UFC) ministrada por mim de 2011 aos dias de hoje.

Agradeço o convite que me foi feito pelas incríveis Lucia Lombardi e Mirian Celeste para participar deste dossiê e dedico este texto à minha mestra-mor da arte-educação, Cleusa Helena Guaita Peralta Castell, com quem aprendi muita coisa do que sou e sei hoje, enquanto profissional e pessoa que me tornei e venho me tornando. É de nossas aventuras acadêmicas, artísticas e estéticas ${ }^{1}$ que brotaram e brotam muitas práticas e metodologias de ontem e hoje, num profundo aprimoramento e transmutação, na ação-reflexão-ação de uma educadora curiosa e incansável que sou.

Tenho consciência de que sou professora de Arte na Pedagogia por ideal, pela defesa do acesso à arte em todos os níveis de ensino, como um direito que todos temos ao autoconhecimento pela via sensível, pela criação e expressão de nossa singularidade, ao olhar estético/poético das realidades. Também porque não consigo suportar a ideia de que milhares de crianças são grosseiramente 


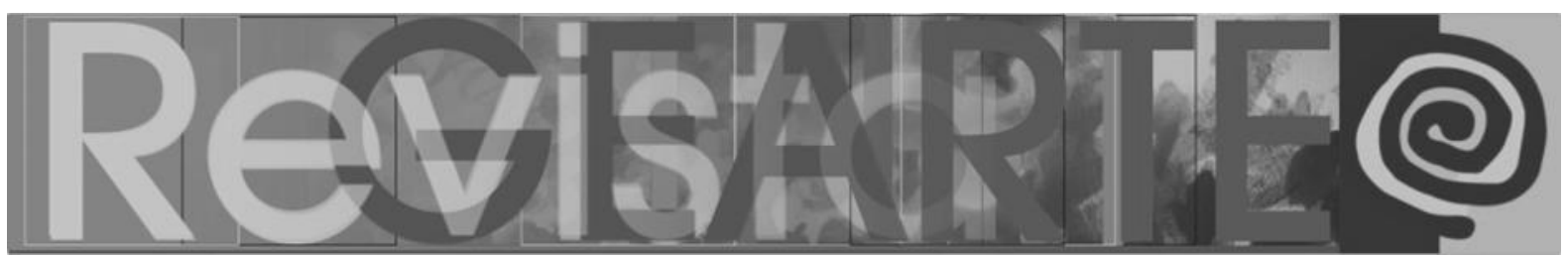

desencorajadas à sua criação e expressão espontânea, tendo seu processo criativo cerceado, bloqueado, interrompido; porque todos e todas, estudantes de Pedagogia, precisam tomar consciência da importância e da necessidade da arte para si e para cada um, não importa a idade; porque é preciso acabar com a perpetuação das práticas pedagógicas vazias e sem sentido na Educação Infantil e no Ensino Fundamental que ainda ocupam o lugar da "arte" na escola; porque arte é conhecimento, arte tem conteúdo específico, arte é componente curricular obrigatório como todos os outros.

Lembro, como se fosse hoje, meus primeiros insights na área da educação, ainda enquanto estudante de Artes Plásticas, nos anos 1990 na Universidade Federal do Rio Grande (FURG/RS). Mesmo estando em uma licenciatura havia poucos colegas interessados na docência e eu era uma das exceções. Simplesmente não me contentava em "olhar apenas para o meu umbigo" (nada contra esse exercício importante ao trabalho autoral artístico), eu queria, afinal, "olhar para o umbigo alheio" e essa minha ânsia por olhar o outro e compreender o outro me levaram a uma série de inserções em projetos como voluntária e bolsista, responsáveis por me iniciarem, significativamente, na docência em arte. Desde então, não fiz outra coisa senão estar envolvida com a educação, experimentando, experenciando, fazendo arte, pensando arte e sentindo arte com os outros, com variados públicos, em diferentes níveis e espaços.

Um grande acontecimento para mim foi o dia em que tomei consciência da importância da história do ensino de arte no Brasil para o entendimento do que constitui as práticas pedagógicas em arte na sala de aula, como se constroem e se desenvolvem as abordagens, as metodologias, os conteúdos e conhecimentos nesse campo e como essas perspectivas interagem, coexistem e fundamentam as representações que se têm sobre a arte na sociedade e, principalmente, na escola. Tornou-se primordial disseminar esse entendimento sobre o poder da história na expressão das práticas existentes hoje, especialmente ao constatarmos ainda as fragilidades e precariedades que insistem em ocupar espaço na escola em nome 


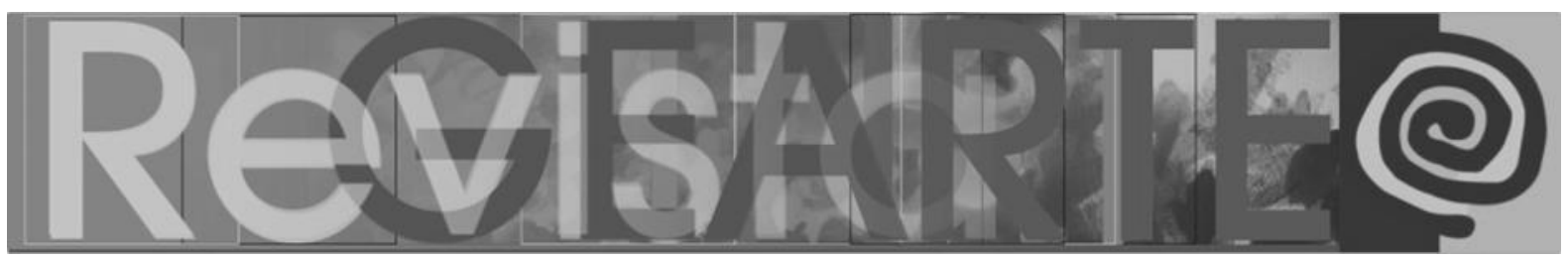

do ensino de arte - um carrossel de equívocos, preconceitos e ignorâncias que se repetem.

Diante dessa realidade sempre me perguntei: como ensinar o que não se teve ou não se sabe? Talvez pela via de um novo paradigma? Pelo paradigma do autoconhecimento que Santos (2008) nos fala? Pela capacidade de espanto e surpresa diante da banalização da vida? Pelo entendimento do desconhecido como oportunidade para criar o novo? Pela escolha da aventura no lugar do previsível controle? Para pensar sobre arte na Pedagogia a partir dessas reflexões, convido você a embarcar comigo na aventura do "espalha-brasa".

\section{Da aventura do "espalha-brasa": metáforas para arte na Pedagogia}

Educar é mostrar a vida a quem ainda não a viu. O educador diz: "Veja!" - e, ao falar aponta. O aluno olha na direção apontada e vê o que nunca viu. O seu mundo se expande. Ele fica mais rico interiormente. E, ficando mais rico interiormente, ele pode sentir mais alegria e dar mais alegria - que é a razão pela qual vivemos. Vivemos para ter alegria e dar alegria. $O$ milagre da educação acontece quando vemos um mundo que nunca havíamos visto.

Rubem Alves (2003, orelha do livro)

Para explicar o título deste capítulo e, mais especificamente deste item, durante alguns anos a imagem que escolhi para estampar a apresentação do programa de ensino da disciplina de Arte e Educação no curso de Pedagogia foi a de um "chapéu mexicano", como conhecemos no Rio Grande do Sul, de onde venho, mas que no Ceará é popularmente conhecido como "espalha-brasa" (Figura 1). 

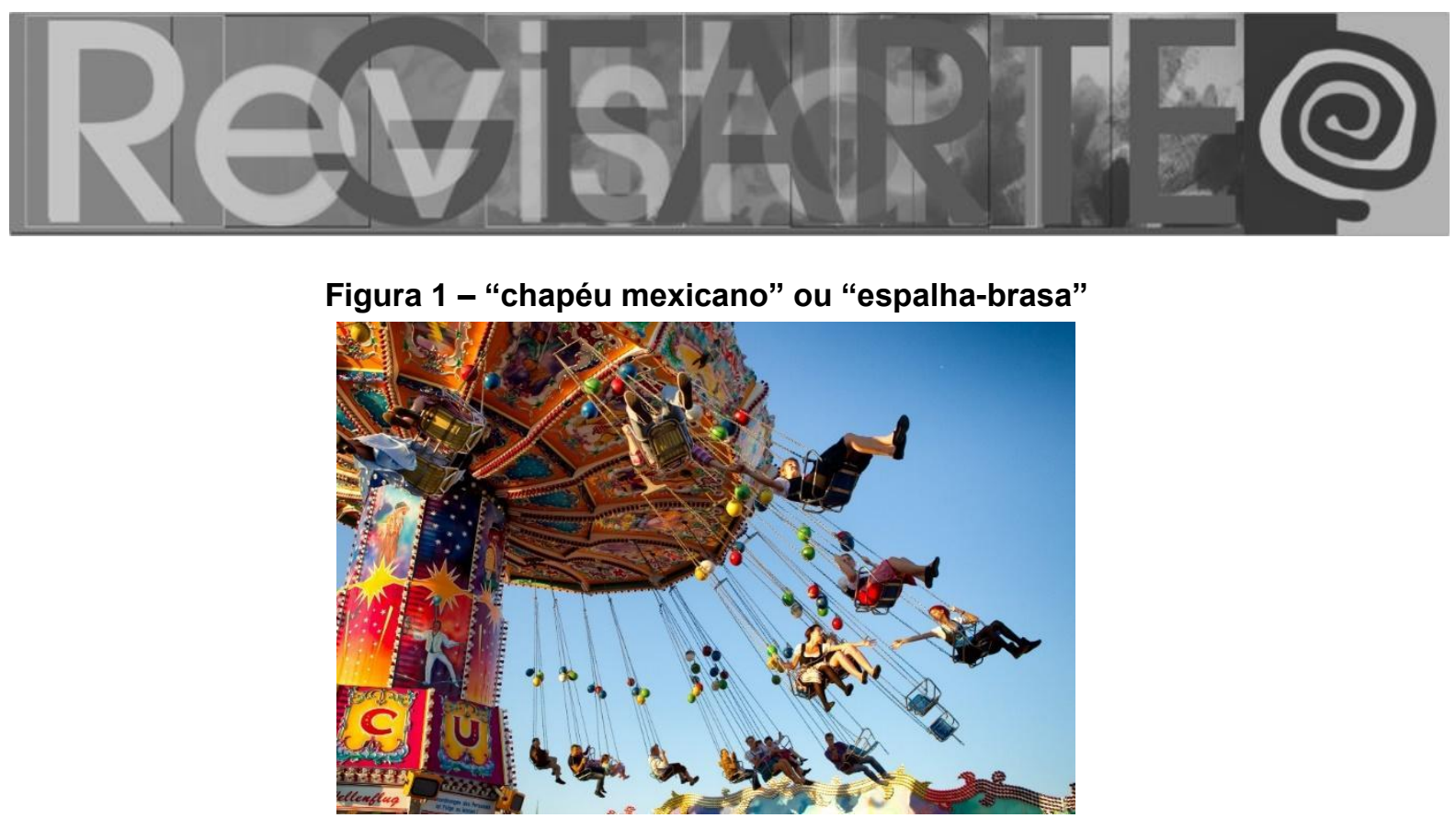

Fonte: Pixabay (2020).

Para iniciar a apresentação da disciplina propunha aos estudantes uma leitura dessa imagem: O que ela representa? Quais sensações, memórias, sentimentos são evocados por ela? O que aparece na imagem, qual elemento se destaca mais? Imediatamente eles se dividiam entre os que já tiveram a experiência em um "espalha-brasa" e os que nunca, jamais tiveram coragem, por medo de que a cadeira voasse, literalmente (!). Para aqueles que já haviam brincado, as sensações relatadas eram de "frio na barriga", "falta de ar", "ânsia de vômito", "sensação de estar voando", "ver tudo de cima", "tudo fica pequenino ao redor", "tudo gira e o olhar muda", "sensação de liberdade".

A partir dessa leitura, evocada pelos sentidos, experiências e percepções dos estudantes trago uma relação metafórica do "espalha-brasa" com a disciplina de Arte e Educação: de início você pode ter medo ou receio, pela novidade, pelo desconhecido, pois a arte nos permite inúmeras sensações e experiências, prazerosas ou não, que provocam emoções diversas. Mas, se você se permitir, se ousar entrar no "espalha-brasa", tudo vai entrar em movimento; vai rodar e rodar até que sua visão de mundo mude, até que você tenha outra perspectiva da realidade; você vai voar e se sentir livre sem sair do lugar; vai ter uma experiência individual e coletiva ao mesmo tempo, "na sua cadeira", com várias pessoas vivendo a mesma experiência; e vai ter cor, luz, movimento, formas, até que tudo será o céu azul infinito e você não será mais a mesma pessoa ao sair. Essa é a 


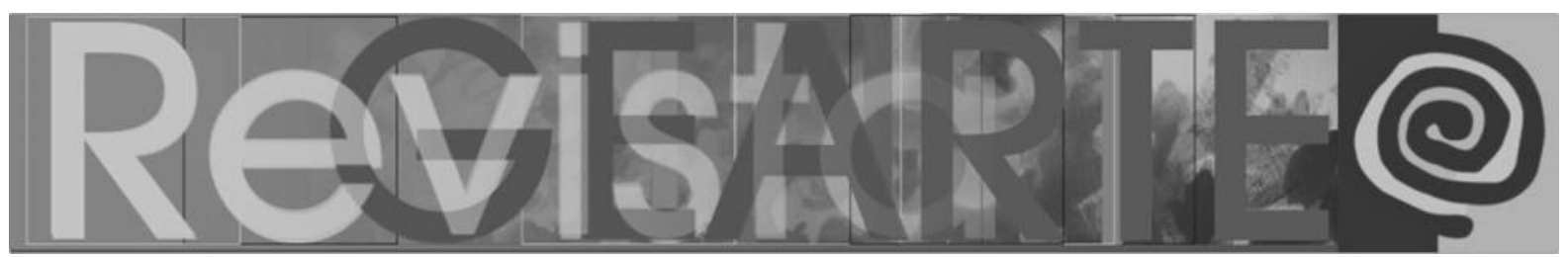

aventura que proponho desde então: um convite ao "espalha-brasa" da Arte Educação!

Creio que para muitos de nós, docentes em Arte na Pedagogia, com formação em uma das áreas da Arte, um dos grandes desafios é lidar com a polivalência da formação em Pedagogia, outro é a curta carga horária para uma disciplina de Arte e Educação, que no caso do curso de Pedagogia da UFC é a única obrigatória da área em todo o currículo, com apenas 64 horas. Assim, ser porta-voz da Arte na Pedagogia, traz a grande responsabilidade de promover experiências, conhecimentos e práticas que contribuam para uma formação séria e comprometida, que, de alguma forma, seja marcante e significativa, já que pontual e reduzida diante de todo um currículo.

Nesse lugar da docência em arte no curso de Pedagogia, minha primeira preocupação foi investigar o que os estudantes sabiam/conheciam/vivenciaram de/sobre/com arte em suas vidas, da trajetória escolar à vida pessoal. Por não termos um currículo em arte, como em outras áreas do conhecimento, não temos nenhuma indicação dos conteúdos trabalhados formalmente. Apesar de os documentos norteadores oficiais para o ensino de arte na escola trazerem princípios, objetivos, conteúdos, métodos, sinceramente, não temos ideia do que as escolas trabalham em arte nas diferentes séries e como trabalham, tanto quanto se as escolas oferecem o ensino de arte obrigatório em todos os anos do Ensino Fundamental.

Se não sabemos como isso acontece na área, ou seja, no Ensino Fundamental II, em que a responsabilidade do componente curricular é do profissional com formação em arte, imagine na Educação Infantil e no Ensino Fundamental I, campo de atuação dos licenciados em Pedagogia - como saber que formação tiveram nos cursos de graduação e se tiveram? Pesquisas realizadas pelo Grupo de Pesquisa Arte na Pedagogia (GPAP) trazem contribuições muito significativas sobre a presença ou não de disciplinas da área de arte nos currículos dos cursos de Pedagogia nas universidades públicas e 


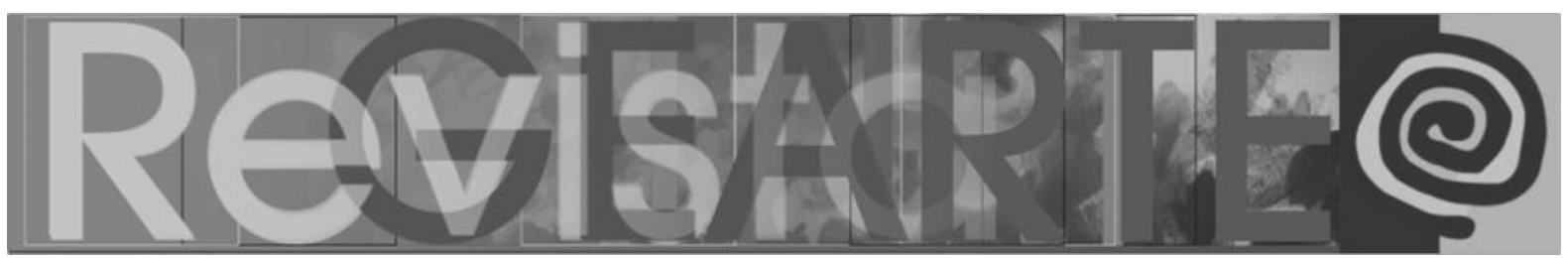

privadas em todo o país, relatando uma realidade bastante delicada e frágil no que tange a formação de pedagogos e pedagogas no campo da arte ${ }^{2}$.

Sendo assim, qual seria o ponto de partida para iniciar um programa de ensino em Arte e Educação na Pedagogia? Por onde começar? O que seria mais significativo e primordial? Como questionam Martins e Lombardi (2015):

\begin{abstract}
Como ampliar a alfabetização também estética? Como promover a formação integral de pedagogos que chegam à universidade com poucas experiências significativas nas linguagens artísticas? Que disciplinas anunciadas por suas ementas e bibliografias dão conta de ir além da prática imediatista tão afeita a técnicas e modelos prontos? Como lidar com a formação cultural e o incentivo à imaginação criadora e à percepção sensível no trato com aprendizes de arte e consigo mesmos? (MARTINS; LOMBARDI, 2015, p. 26)
\end{abstract}

Como podemos ver, são muitos os questionamentos. De minha parte, não consegui e não consigo, até hoje, imaginar um planejamento que não parta de conhecimentos prévios dos estudantes, das características pessoais deles, de quem são - qual classe social, de onde vêm - qual contexto cultural. Assim, para mim, só fazia e faz sentido pensar essa experiência a partir dos próprios estudantes.

Da história do ensino de Arte no Brasil como um todo, à nossa história de vida, produzimos um diálogo constante entre o micro e o macro, que nos conecta à perspectiva do singular-plural (FERRAROTTI, 2014), por sermos e nos constituirmos em seres históricos e contextualizados. Portanto, o trabalho autobiográfico, ganhou cada vez mais força na minha prática docente, pelo potencial de resgatar a história de cada um e conectar esses fatos biográficos e geracionais a uma história maior, de toda uma sociedade. Essa perspectiva vem respondendo, a cada dia com mais intensidade, sobre a importância desse mergulho em quem somos nós, nas vivências artísticas e estéticas que tivemos a oportunidade de experienciar e na influência que isso tem diante nossos (pré)conceitos, visões, práticas, posturas e metodologias ainda presentes nas salas de aula desse nosso gigante país. Essa perspectiva fundamenta algumas das ações desenvolvidas na disciplina. 


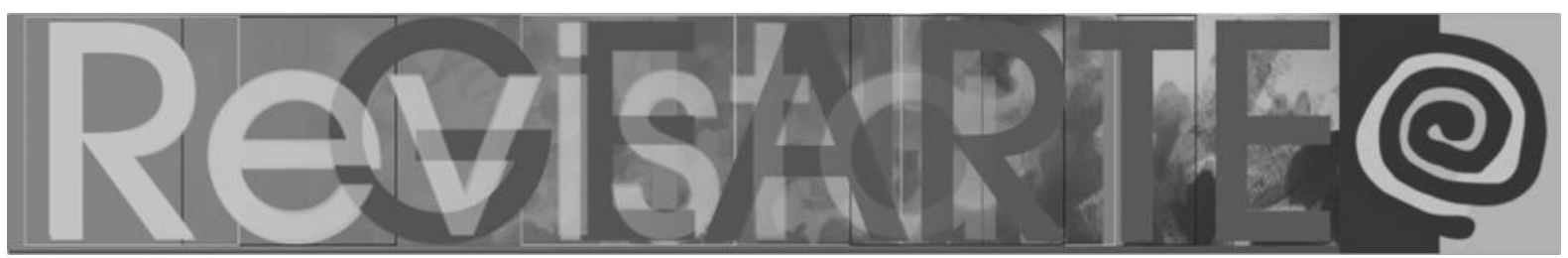

Outra questão pungente é o conhecimento sobre desenho infantil na formação em Pedagogia. Como podem pedagogos e pedagogas não terem conhecimentos sobre uma das linguagens mais potentes da criança e, pior, como podem contribuir para seu embotamento? Costumeiramente recebo um arsenal de relatos cotidianos de atrocidades cometidas com as crianças nesse lugar inaceitáveis! Desde que compreendi mais profundamente sobre a importância do desenho infantil para o desenvolvimento humano, passei a ser porta-voz desses conhecimentos $^{3}$. Assim, estudamos o grafismo infantil partindo do processo de cada estudante, proporcionando um olhar sobre seu desenho na perspectiva de resgate da capacidade criadora do educador e da compreensão de seu papel na valorização, compreensão e incentivo dessa linguagem para a criança. O que descrevo no último item deste texto.

Diante da realidade e das dificuldades da área, me propus a desenvolver metodologias participativas em que eu pudesse conhecer o público de estudantes do curso de Pedagogia, o que sabem sobre arte, como se relacionam com a arte, que experiências artísticas e estéticas puderam vivenciar, que conteúdos artísticos tiveram acesso em sua trajetória escolar, e que eles também pudessem mergulhar e suas próprias vidas para entender onde esteve e está a arte ali vivida/experienciada, qual o significado formativo dessas vivências, ressignificando e projetando possíveis e novos olhares para a arte na escola ou em espaços nãoescolares, sobre o que, como e porque ensinar arte.

Opto então por metodologias processuais e vivenciais, de profundo envolvimento em que nada está dado, pronto ou pode ser previsto, no improviso constante de educadores que se experimentam no lugar da liberdade, da autonomia e da autoridade partilhada na horizontalidade das relações em sala de aula. São muitas as ações e experiências realizadas, aqui vou partilhar somente algumas delas. Então, comecemos do princípio de tudo, do que seria, afinal, "Arte" através de uma dinâmica que relato a seguir. 


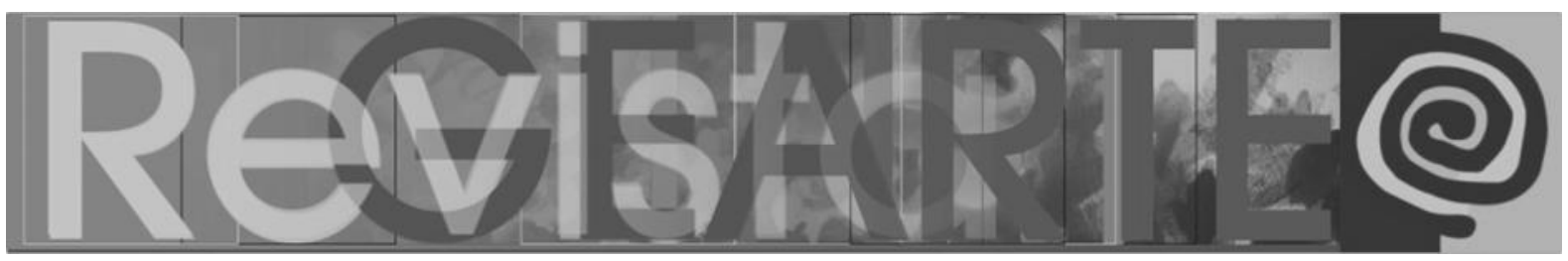

\title{
Das (in)definições de arte: reflexões infinitas, mutáveis e coloridas
}

\begin{abstract}
À pergunta "O que é arte?" muitos sábios já propuseram suas respostas, mas nunca nenhuma delas conseguiu satisfazer a todos. $A$ arte é uma dessas coisas que, como o ar ou o solo, estão por toda a nossa volta, mas que raramente nos detemos para considerar. Pois a arte não é apenas algo que encontramos nos museus e nas galerias de arte ou em antigas cidades como Florença ou Roma. A arte, seja lá como a definimos, está presente em tudo que fazemos para satisfazer nossos sentidos. Herbert Read (2001, p.16)
\end{abstract}

Depois das apresentações da turma, do plano de ensino da disciplina, para o começo de tudo pensei: afinal, sabemos o que é arte? Já paramos para pensar e refletir sobre o que é arte? Uma das definições mais escorregadia e complexa da História, eu diria, mas a reflexão, portanto, se faz ainda mais necessária. Para este desafio criei uma dinâmica muito simples, mas extremamente profícua e que gera os mais acalorados debates e reflexões sobre o que vem a ser arte. Uma metodologia muito simples que traz resultados exponenciais mutantes que se transformam em infinitas definições que servem ao puro exercício da reflexão, sem preocupação sobre o que é certo ou errado, sem comparações entre melhor ou pior, bom ou ruim.

Explicando, saí em busca de diferentes definições de arte ao longo da História - sabemos que a arte se transforma e vai ganhando novos formatos, materiais e significados que geram diferentes representações sociais que acabam transitando até os dias de hoje e que, de alguma forma, influenciam diretamente nas práticas docentes presentes em nossa sociedade, da arte clássica à arte contemporânea.

A partir de diferentes definições de arte que encontrei nos mais variados livros de História da Arte extraí palavras-chave, como: "dom", "bom gosto", "perfeição", "talento", "genialidade", "harmonia", "atemporal", "fruição", "clássico", "tradição", "excêntrico", "vanguarda", "imaginário", "fantasia", "universal", 


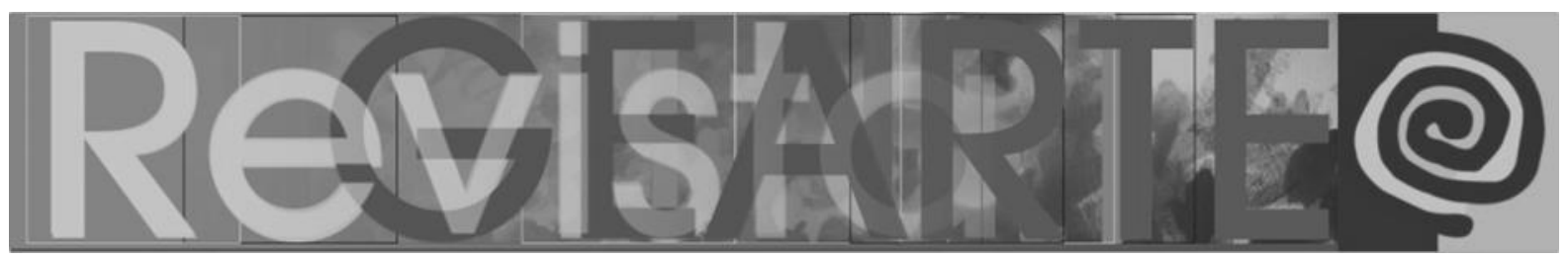

"habilidade", "técnica”, "forma e conteúdo", "subjetividade", "invenção", "coragem", "beleza", "tempo", "criatividade", "cultura", "liberdade", entre outras. Para cada palavra apliquei uma cor, formando grupos de palavras de cinco cores diferentes (amarelo, azul, vermelho, verde e rosa). Cada estudante recebe, então, uma palavra em uma cor e se reúnem nos grupos por cor, o que faz com que se misturem entre si, interagindo com diferentes colegas da turma.

O desafio é: "defina arte usando as palavras". Os estudantes devem elaborar uma definição de arte não muito longa, podendo negar as palavras ou alterá-las sem mudar o sentido. Começa então o primeiro debate, no interior de cada grupo, momento em que os integrantes começam a pensar no sentido das palavras, tiram dúvidas sobre as palavras que não conhecem, colocam seus posicionamentos, se concordam ou não com as palavras nas suas visões e entram em negociação, criando uma dinâmica interna para chegar a um consenso na elaboração da definição. Esse processo é riquíssimo!

Concluída esta parte vamos para o grande debate, em que cada grupo apresenta sua definição, compartilha como foi o processo, aponta as dificuldades, as desavenças do grupo (se houver), explica como chegou à definição e, de alguma forma, a defende. No grande grupo temos as mais ricas e interessantes reflexões, discussões acaloradas, posicionamentos críticos, relatos de casos do cotidiano, exemplos de situações vividas.

A partir das definições é possível vislumbrar as ideias que os estudantes trazem sobre o que é arte, como articulam e defendem seus pensamentos, o que não concordam. Se inicia um vigoroso processo de quebra de paradigmas, de acesso a novos olhares e visões diante do que seria arte. A multiplicidade de definições, todas válidas, escapam da cristalização de uma verdade, desconstroem certezas, relativizam posturas e posicionamentos - em arte pode ser e pode não ser! Quase tudo pode! Quanta liberdade há na arte - quanto mais tentamos defini-la, mais ela nos escapa, mais ela se mostra escorregadia, mutante, multifacetada, controversa - que dificuldades temos diante disso? Como lidamos 


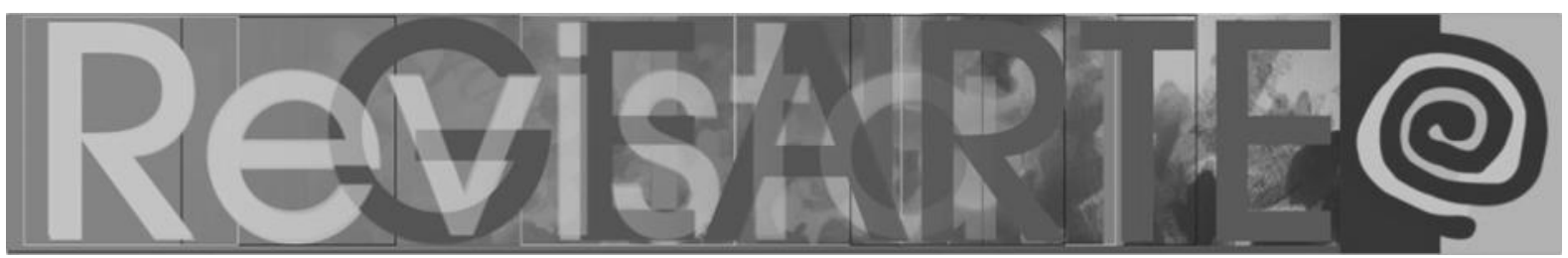

com aquilo que não controlamos, especialmente em uma sociedade de respostas certas e prontas.

Nas avaliações dos estudantes, eles partilham a importância de se pensar no significado das palavras, nas intenções por trás delas, no que elas carregam em seus sentidos; percebem que não existe somente uma definição de arte, que a arte muda a todo instante e que, historicamente, vai apresentar distintas visões e definições em diferentes contextos sociais e culturais; observam que a metodologia abre um leque reflexivo, participativo e integrativo, em que mudam as palavras, mudam as pessoas, mudam as definições. Finalizamos nos questionando - como relacionar Arte com Educação?

Completamos essas reflexões com leituras iniciais para estudantes de Pedagogia, que em sua maioria, não possuem aprofundamento teórico na área. A bibliografia sempre sofre alterações, porém trazemos como propostas de leitura o texto "O que pode a educação aprender das artes sobre a prática da educação?", de Elliot Eisner (2008), o capítulo "Como a Arte Educa" do livro Fundamentos Estéticos da Educação, de Duarte Júnior (2002), o capítulo "A definição de arte", de Herbert Read (2001), entre outros mais contemporâneos. No próximo item partilho algumas ações de cunho autobiográfico, coluna vertebral da disciplina de Arte e Educação ministrada por mim.

\section{Da Linha do Tempo ao Autorretrato: mergulhos autobiográficos formativos}

A reflexão biográfica prepara e dispõe o sujeito para a formabilidade, ou seja, para a sua capacidade de tomar consciência de si como aprendente, de saber observar o que aprende e como aprende, e de decidir o que fazer com o que aprendeu.

Maria da Conceição Passeggi (2008, p. 18-19)

Aqui partilharei sobre duas propostas realizadas na disciplina de Arte e Educação que permanecem, a cada semestre, se reinventando e transformando visões de mundo de pedagogos e pedagogas em formação. Ambas tratam de 


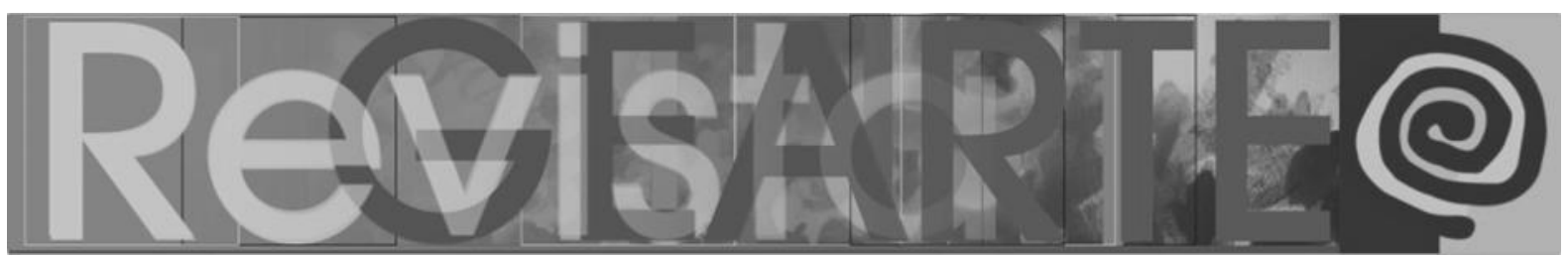

aspectos autobiográficos dos estudantes, porém em níveis e expressões distintas. Na primeira, a chamada Linha do Tempo, os estudantes narram, da forma como quiserem, sobre as experiências formativas em arte em suas vidas, da infância aos dias de hoje, na segunda, o Autorretrato, é a oportunidade de experienciar o fazer artístico representando a si mesmos a partir de um processo metodológico estruturado e organizado. Pela primeira, nós entendemos como parte de um grupo social, como cúmplices, como linhas conectadas na grande teia da vida, como participantes da História, na segunda recuperamos a espontaneidade criadora e lúdica da arte através de uma ambiência favorável, em que não há modelos, julgamentos ou competições e cada um pode ousar ser quem é.

Objeto de reflexões e publicações em livros e em congressos desde $2012^{4}$, a ação acadêmica "Linha do Tempo" - como experiência de formação - já possibilitou a mais de mil estudantes a narrativa e reflexão sobre suas experiências formativas em Arte. Essa aventura iniciou em 2008, quando eu ministrava a disciplina "Fundamentos e História da Arte-Educação", no curso de Pós-graduação em Arte e Educação Lato Sensu do Centro Universitário 7 de Setembro (UNI7) em Fortaleza (CE) e procurava um meio criativo e potente de trabalhar a história do ensino de arte no Brasil, algo que pudesse ser vivido, sentido para depois ser alimentado pelo conteúdo teórico, construindo um diálogo entre o ontem e o hoje.

Na UFC, realizo esse trabalho desde 2011 até os dias atuais, na Pedagogia, na disciplina de Arte e Educação e já realizei com algumas turmas da Licenciatura em Teatro, na disciplina de Fundamentos da Arte na Educação. Metodologicamente, os estudantes são convidados a elaborar, individualmente, e fora da sala de aula, um pequeno inventário de suas vidas, focando nas experiências formativas em arte desde a infância até a atualidade e, posteriormente, compartilhá-lo com o restante do grupo por meio de uma narrativa (de formato livre), com a utilização de recursos por eles escolhidos.

Devido à grande quantidade de estudantes nas turmas de Arte e Educação (média de 40), os estudantes têm até dez minutos para apresentarem suas 


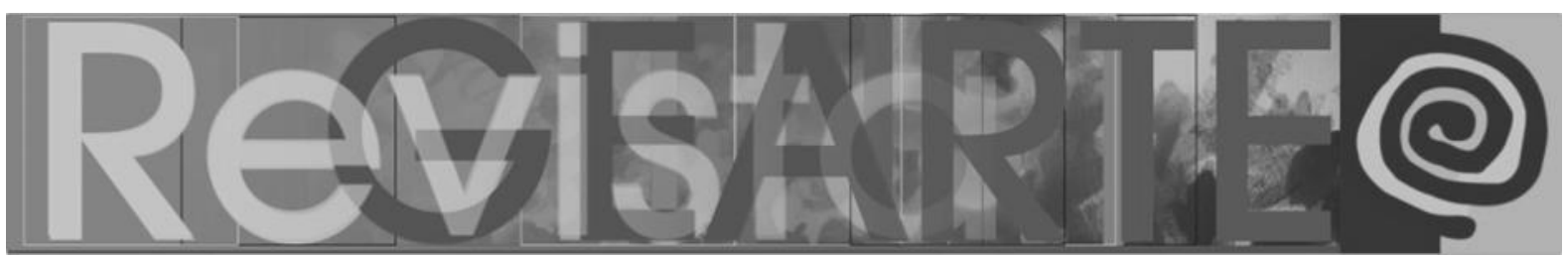

narrativas. Após todas as apresentações realizamos uma síntese reflexiva em que o grupo se debruça sobre as narrativas, interpretando-as e fazendo análise crítica de tudo que foi compartilhado; com base em Barbosa (2002), Ferraz e Fusari (1993) e Silva e Araújo (2007) relacionando com o conteúdo das linhas do tempo apresentadas; por fim eles elaboram uma análise crítica textual contendo três etapas: análise geral de todas as Linhas do Tempo apresentadas, análise individual e autoavaliação e análise crítica dos conteúdos que emergiram relacionando com o histórico do ensino de arte no Brasil (GOLDBERG, BEZERRA; PEREIRA JUNIOR, 2018).

Impossível relatar o que acontece quando a ação inicia, só quem vive, sabe! Cria-se um clima gostoso de troca, de cumplicidade, de confiança no outro, afinal estamos partilhando conteúdos sensíveis e pessoais de nossas vidas, estamos nos expondo (!). A liberdade de criação para a elaboração das narrativas leva às mais variadas ideias e formatos, são tantos que não podemos aqui enumerar, exemplificar ou ilustrar. Nesses dias de apresentação cantamos, dançamos, gargalhamos, choramos, nos emocionamos coletivamente, conhecemos o outro e a nós mesmos, nos acolhemos, nos aceitamos, nos percebemos, nos indignamos, nos fortalecemos enquanto sujeitos.

Esse exercício, pelo caminho do biográfico, leva a uma aprendizagem significativa que extrapola a sala de aula e os conteúdos em si, transformando a realidade de muitos estudantes que, após passarem por esse processo almejam mudanças, engendram e buscam novos caminhos, planejam e projetam propostas para um futuro diferente, que proporcionem verdadeiras e significativas experiências formativas em arte para si e para os outros enquanto futuros educadores. A ação nos apresenta uma realidade bastante desoladora no que tange à arte na escola,

[...] é preocupante e, por que não dizer, assustador, ver como pessoas tão diferentes, com idades e trajetórias de vida diferentes trazem experiências praticamente iguais quando se trata de arte na infância. É contrastante observarmos que a arte, elemento de potencial criativo, transformador e promotor de singularidade se converte na escola em 


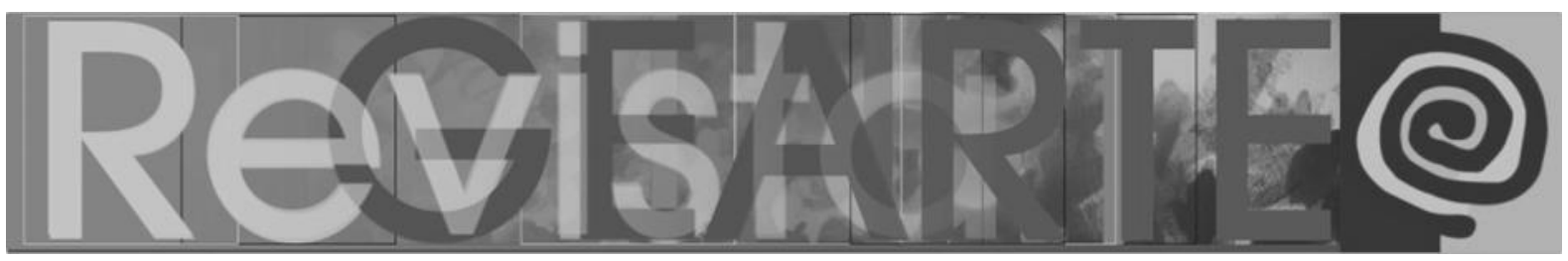

atividades pontuais, de cópia, reprodução e repetição. Na escola narrada não existe espaço para a criação e a invenção, é preciso pintar dentro da linha, em um só sentido na cor imposta, um desenho que já vem pronto, e essa é a "aula de arte"! (GOLDBERG, 2014, p. 225).

Por mais que pareça "óbvio" para muitos de nós arte-educadores o entendimento dessa realidade da arte na escola, para os estudantes de Pedagogia não há uma consciência clara dos aspectos históricos que contribuíram para as experiências artísticas vividas por eles na escola. Conhecer esses fatos históricos leva à interpretação da realidade atual, identificando as práticas pedagógicas experenciadas enquanto estudantes na fase escolar e agora universitária. Que práticas são essas? De onde vêm? Como se multiplicam? Por que acontecem dessa forma? Como podemos fazer diferente?

A Linha do Tempo se propõe à reflexão e ao diagnóstico da realidade do ensino de arte pela via do biográfico, permitindo uma grande crítica e a desconstrução de muitos (pré)conceitos e visões que os estudantes trazem, apontando para a responsabilidade dos futuros educadores - como posso contribuir para as narrativas futuras das novas gerações? Não temos respostas ainda, mas tenho visto muita coisa mudar desde então nos relatos de pedagogos e pedagogas que viveram o processo da Linha do Tempo e hoje estão nas escolas. Muitos voltaram a desenhar, dançar, cantar, atuar, muitos buscaram novas práticas e experiências em arte fazendo cursos e formações, muitos buscam proporcionar o que não tiveram. Muitos despertaram!

Seguindo nessa perspectiva autobiográfica, vamos agora à ação do Autorretrato! ${ }^{5}$ A primeira vez que realizei essa oficina no curso de Pedagogia na UFC foi em 2014, retomando em 2017 e desde então estudantes pedem, a cada semestre, para fazerem seus autorretratos. Não é para menos, pois a cada semestre fazemos uma exposição dos autorretratos dos estudantes na disciplina de Arte e Educação na entrada da faculdade (ver Figuras 2 e 3) e a comunidade passa a interagir com os trabalhos, o que gera expectativa nos futuros estudantes que ainda cursarão a disciplina, que já chegam à disciplina com o desejo de 


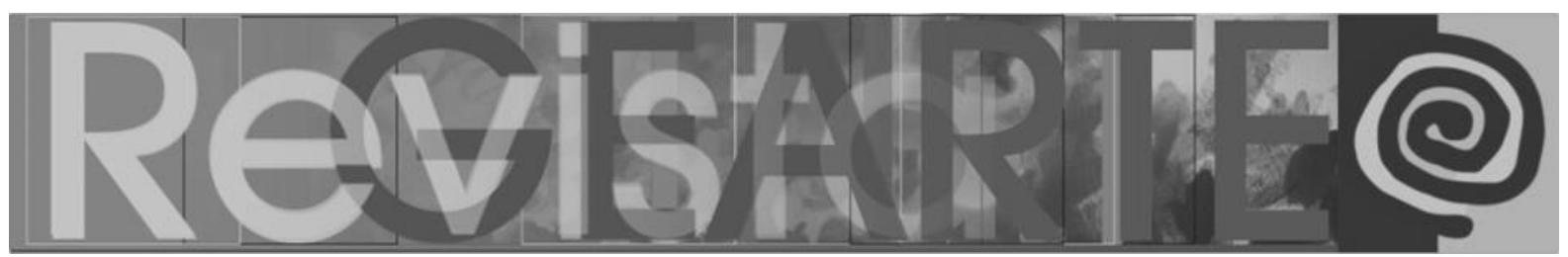

fazerem seu autorretrato! Já perdi a conta de quantos estudantes já fizeram seus autorretratos e tenho que admitir que a ação ganhou repercussão pelos belos trabalhos realizados, fruto de admiração de todos da comunidade acadêmica. Virou um clássico!

Figura 2 - Exposição de autorretratos da disciplina de Arte e Educação (FACED/UFC), 2018

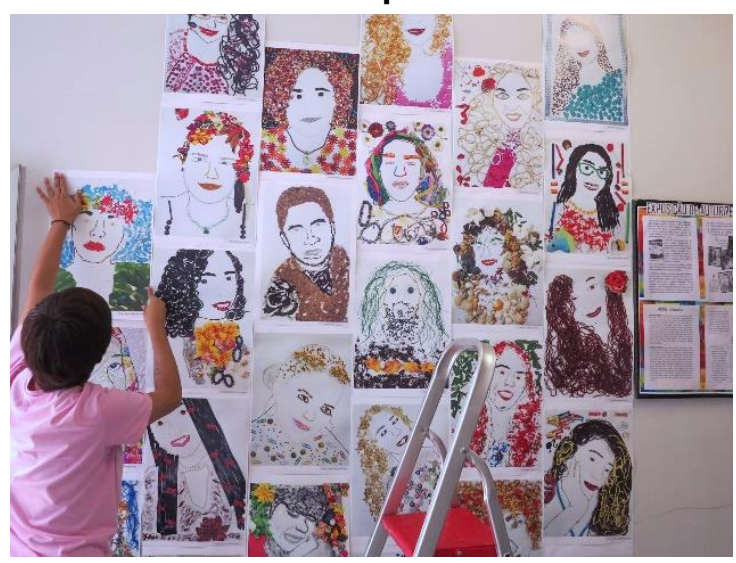

Fonte: Arquivo da disciplina de Arte e Educação, Luciane Goldberg (2018).

Figura 3 - Exposição de Autorretratos - FACED/UFC

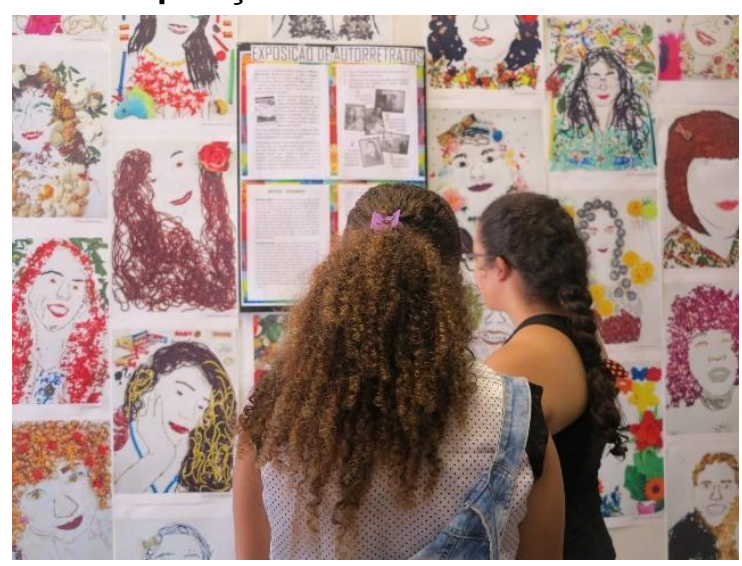

Fonte: Arquivo da disciplina de Arte e Educação, Luciane Goldberg (2018).

Inspirada na obra do artista contemporâneo brasileiro Vik Muniz e na Abordagem Triangular sistematizada por Ana Mae Barbosa, que pressupõe a aprendizagem significativa, por meio de uma triangulação que considera e conecta "o fazer, a leitura de obras de arte ou do campo do sensível e a contextualização, que seja histórica, cultural, social, etc." (BARBOSA, 2010, p. 32), partimos do contato com a obra do artista visual brasileiro Vik Muniz, através do documentário "Lixo Extraordinário". No documentário é possível acessar o trabalho do artista 


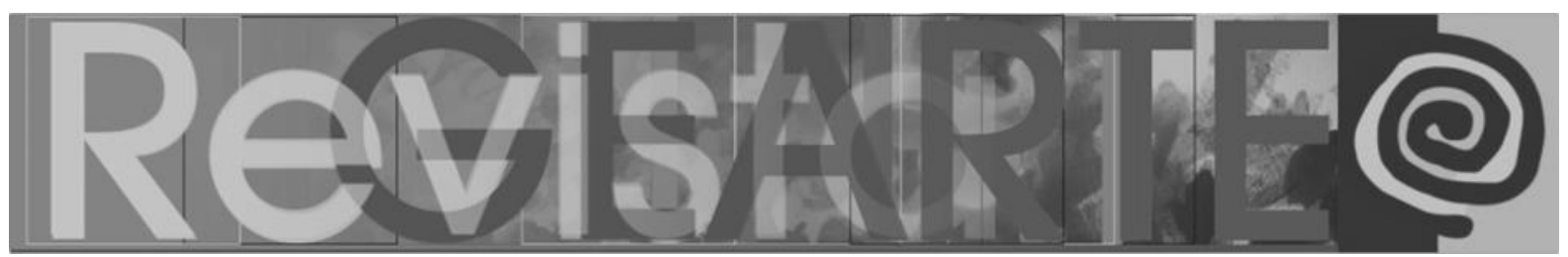

junto aos catadores de lixo reciclável para a realização dos seus retratos e, também acompanhar como o artista compõe as obras. Matéria e material são chaves para a conexão entre a obra e o sujeito retratado, o que caracteriza o trabalho do artista, o qual é conhecido pela diversidade, variedade e criatividade no uso e escolha dos materiais que compõem suas obras.

Após leitura, contextualização, debate e estudo da obra do artista Vik Muniz, os estudantes são convidados a fazerem seus autorretratos, sendo instigados a pesquisar materiais que se conectem consigo, que Ihes identifiquem e falem de si para a realização de seus retratos, o que leva a uma grande variedade de materiais e possibilidades estéticas criadas a partir dessa diversidade. Com base na metodologia do artista seguimos o passo a passo: 1) envio de uma foto de retrato por e-mail; 2) desenho da foto projetada; 3) montagem dos retratos em cima do desenho com os materiais selecionados; 4) fotografia do retrato; 5) desmonte do retrato original e 6) exposição dos autorretratos (ver Figuras 3 a 6). Explicarei a seguir alguns detalhes.

Figuras 4 a 7 - Passo a passo da oficina de autorretrato
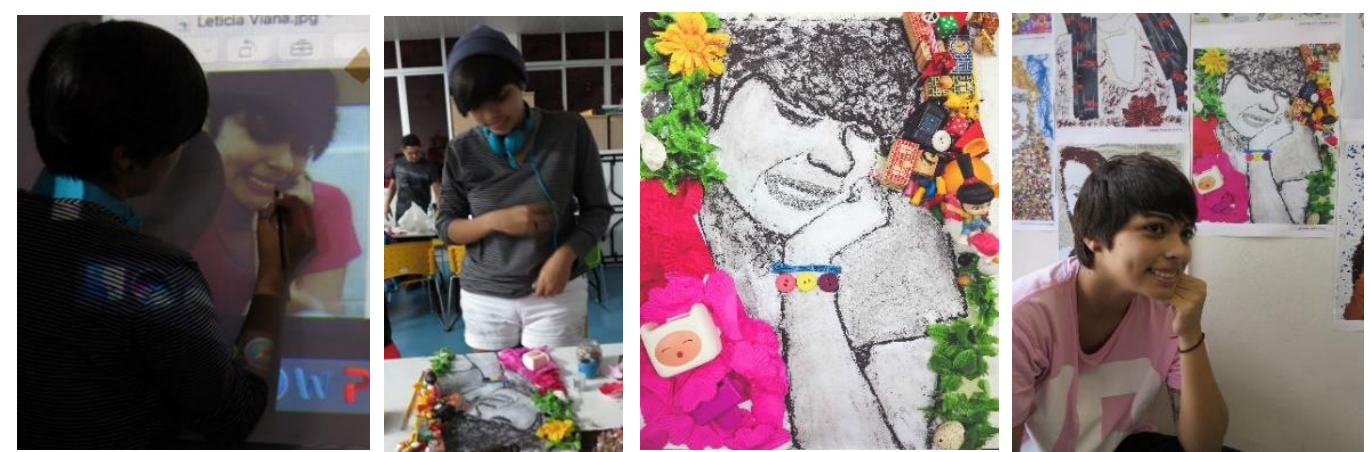

Fonte: Arquivo da disciplina de Arte e Educação, FACED/UFC, Luciane Goldberg (2017).

Há todo um trabalho de produção por trás da realização dessa oficina que inicia com o envio dos retratos/fotografias dos estudantes por e-mail e a organização dos arquivos em pastas por turma, pois como são muitos estudantes (aproximadamente 40 a 45 por turma, sendo duas turmas por semestre, diurno e noturno) é preciso ter todas as imagens nos computadores, dos quais serão projetadas para o desenho. Deixar que cada estudante traga sua foto no dia 


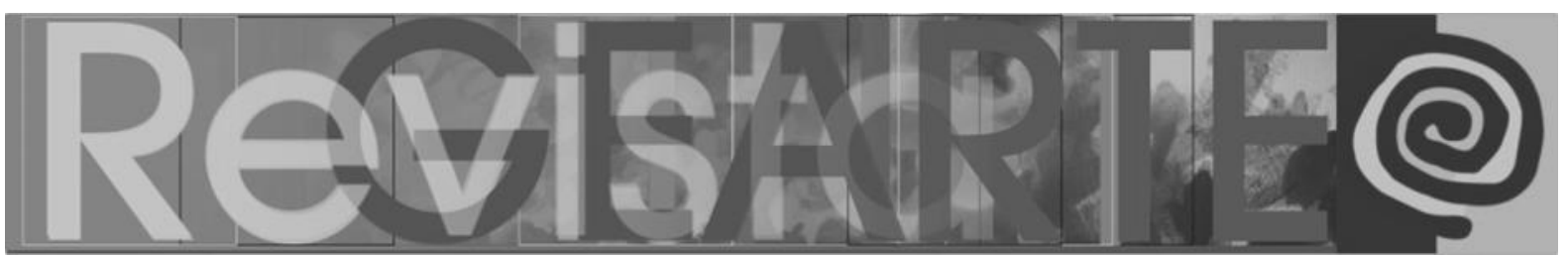

usando celulares, pen drives ou outros dispositivos toma muito tempo e gera confusão, portanto é imprescindível esse envio antecipado.

É preciso ter um momento para o desenho dos retratos projetados e isso toma bastante tempo! Portanto, é preciso planejar as horas/aula disponíveis para a oficina. Como temos quatro horas-aula por semana, reservo dois encontros (8h) para a realização da oficina: no dia em que vemos o documentário fazemos um debate e temos tempo de iniciar a realização dos desenhos, na aula seguinte continuamos os desenhos e fazemos a montagem com os materiais. Buscamos ter mais de um computador e projetores, pois em cada computador é possível projetar dois retratos por vez, por isso precisamos de tempo diante da quantidade de estudantes. Usamos folha de papel tamanho A3, lápis grafite e borracha para o desenho. Essa técnica auxilia muito, especialmente àqueles que dizem que não sabem desenhar e jamais teriam coragem de fazer um autorretrato. Com o auxílio da projeção é só cobrir por cima as linhas principais do retrato e os colegas podem se ajudar se quiserem. Geralmente é preciso mais tempo até que todos desenhem - peço aos estudantes que cheguem mais cedo na aula seguinte, os que puderem, e os demais farão os desenhos no dia mesmo da oficina, os que já desenharam já vão montando seus retratos.

É extremamente necessária uma sala de aula com mesas grandes com espaço para apoio dos desenhos, ou então eles podem ser feitos no chão, apesar de não ser muito confortável. Importante atentar que depois de começado o trabalho de montagem, não é possível mover a folha, pois os materiais não são colados no desenho no papel, são apenas justapostos, colocados sobre! Cuidar também o vento, o ar-condicionado, especialmente quando usam grãos leves como café, canela etc.

Depois da montagem vem a parte da fotografia dos autorretratos finalizados. Se você tiver a ajuda de algum profissional ajuda muito, senão é preciso ter uma câmera boa capaz de captar os detalhes dos materiais usados, essa é a grande riqueza desse trabalho. A responsabilidade pela qualidade da fotografia é imensa 


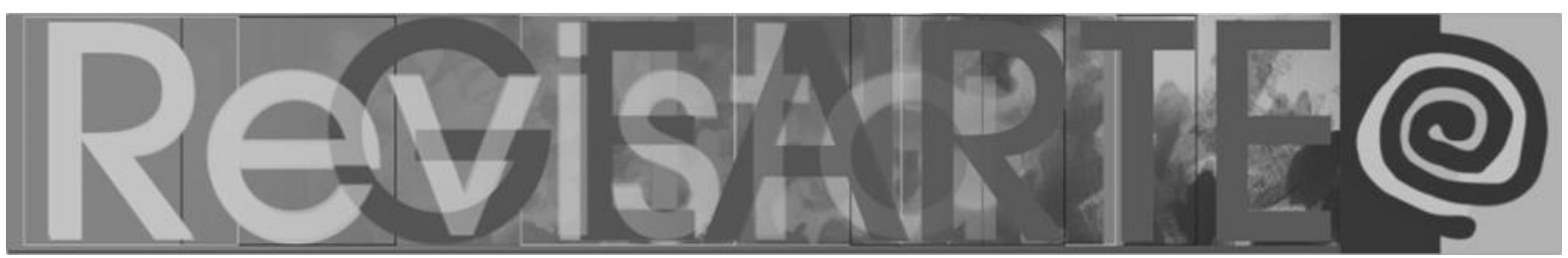

se imaginarmos que após seu registro os trabalhos são desfeitos e a obra de arte é a própria fotografia. Os estudantes ajudam com as lanternas dos celulares para melhorar a iluminação e minimizar as sombras já que a sala de aula não tem uma iluminação própria para tal e somos amadores, não temos tripés e equipamentos apropriados.

Posteriormente é preciso selecionar as melhores imagens e encaminhar para o tratamento para que fiquem com a mesma linguagem visual equilibrando matizes e iluminação. Sempre solicito uma contribuição financeira dos estudantes para a impressão dos retratos, que depois de expostos eles levam para casa. Imagens prontas, dinheiro na mão, vamos à uma gráfica rápida de qualidade para a impressão, depois é organizar um momento em que os estudantes possam auxiliar na montagem da exposição. Exposição pronta, estamos livres para os sorrisos, as fotos, os comentários dos passantes, voilá!

As aprendizagens dessa oficina são muito significativas para educadores em formação, pois através dela podem vivenciar todo um processo pedagógico artístico que vai da escolha do artista e do conhecimento e contextualização da obra do mesmo; da apropriação metodológica realizada pelo artista e adaptada para nossa realidade; da escolha dos retratos e dos materiais a serem usados, buscando conectá-los ao seu processo autobiográfico; do próprio fazer artístico, momento em que cada um faz seu autorretrato e se depara com acertos e erros, com as propriedades de cada material, com os desejos e as expectativas, todo um fazer lúdico pleno de experimentação e liberdade; da captura dos retratos e do desmanche das obras (momento bastante sofrido para muitos); da avaliação da atividade à exposição dos trabalhos. Processo completo com início/meio/fim e continuidades, como a possibilidade de replicação da oficina, o que muitos fazem com públicos diversos e partilham excelentes resultados.

Uma das maiores alegrias é ver a satisfação de cada um, a autoestima elevada diante da realização do seu autorretrato, a autoconfiança restabelecida: "eu sou capaz". Quando concluímos tudo, fazemos uma apreciação dos trabalhos 


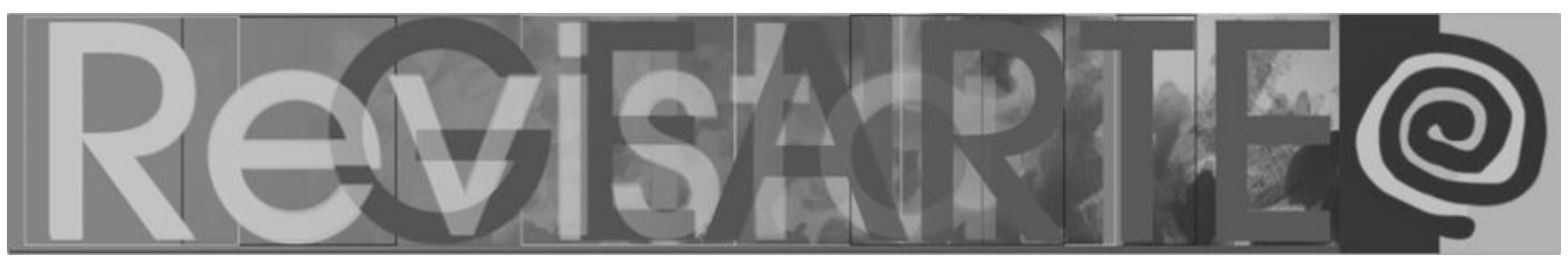

avaliando a proposta. Os depoimentos são marcantes e trazem a certeza de que é possível fazer arte e se sentir satisfeito sem ser artista, assim como é vital criar uma ambiência que propicie a autoconfiança necessária à criação e a valorização da singularidade de cada trabalho artístico, livre de modelos, julgamentos e comparações: a riqueza está na variedade! O tema é o mesmo, autorretrato, mas cada um é único, diferente e especial, isso é arte!

\title{
Do "eu não sei desenhar": resgate da capacidade criadora
}

\begin{abstract}
Quem sabe a linha se torne a protagonista de um campo de acontecimentos potente, não comparecendo apenas como elemento submisso a uma ordem e a uma organização da linguagem 'a priori', e assim cumprindo a vocação máxima do desenho como linguagem expressiva que revele os traços poéticos da subjetividade humana, em nosso caso, as crianças e nossas infâncias adormecidas.

Edith Derdyk (ano, p.135)
\end{abstract}

Por fim, e não menos importante, quero partilhar como desenvolvo o estudo do desenho infantil na disciplina de Arte e Educação na Pedagogia, conteúdo que não abro mão, como já disse no início deste texto. As práticas pedagógicas que desenvolvo estão diretamente conectadas às aprendizagens e estudos que fiz ao longo de minha formação acadêmica desde a graduação em Artes Plásticas e muito devo à Cleusa Peralta Castell pela iniciação ao tema que venho aprofundando até os dias de hoje ${ }^{6}$.

Inicio esse conteúdo com o que chamo de "desenho diagnóstico": peço aos estudantes para desenharem uma figura humana completa, do jeito que sabem fazer e interdito o "boneco palito" explicando que o objetivo é conhecer o desenho original deles e entender onde e se pararam de desenhar. A maioria sofre já que crê não saber desenhar e não aceita ser adulto desenhando ainda como criança (um preconceito que destaco para nossa reflexão em sala).

Segundo os mais variados referenciais do desenho infantil, via de regra, a maioria das pessoas param de desenhar aos seis, sete anos de idade quando inicia

GOLDBERG, Luciane Germano. A aventura do “espalha-brasa”: arte na Pedagogia na Universidade Federal do Ceará. 452 Revista GEARTE, Porto Alegre, v. 8, n. 2, p. 434-458, maio/ago. 2021.

Disponível em: http://seer.ufrgs.br/gearte 


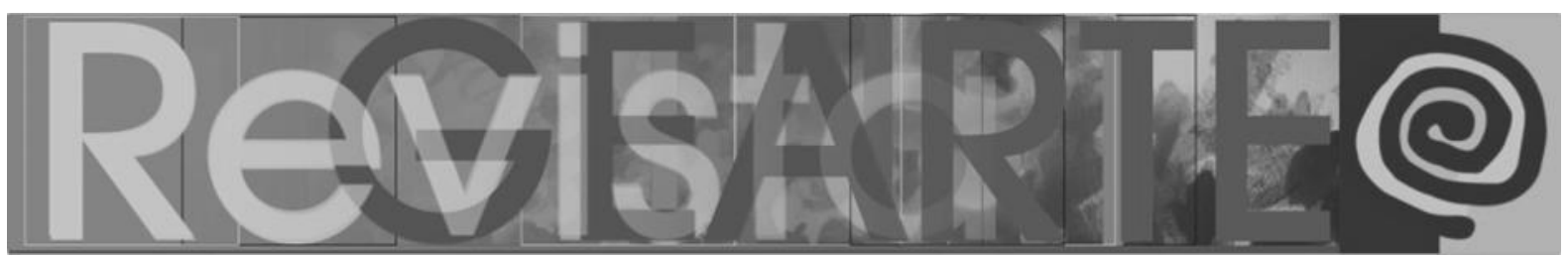

o processo de alfabetização e, como escrever é mais importante que desenhar e desenhar é "só para quem sabe", para quem consegue atender aos padrões de beleza estabelecidos, há um abandono geral dessa linguagem, como nos diz Derdyk (2014):

\begin{abstract}
O que podemos observar é que, na maioria dos casos, as crianças deixam de desenhar quando começam o aprendizado da escrita e, provavelmente, um dos fatores que podem contribuir para essa 'substituição' seria exatamente a perda de sentido do papel e lápis como instrumentos de expressão, agora entendidos como instrumentos funcionais. (DERDYK, 2014, p. 132)
\end{abstract}

E, se desenho é processo, se eu interrompo esse processo, meu desenho fica lá onde eu parei, um entendimento extremamente importante para todos: não é que eu não saiba desenhar, eu simplesmente parei em algum momento em que deveria ter continuado, e, por incrível que pareça, eu posso voltar e retomar de onde parei. A maioria parece retornar à infância enquanto desenha, como uma grande máquina do tempo tudo volta, a vergonha do desenho, escondendo-o dos colegas; a dificuldade em fazer as mãos e os pés, escondendo-os; o prazer em reviver algo que ficou perdido no tempo. Os comportamentos entre si revelam traumas, memórias, alegrias, frustrações, medos. Peço que ao final coloquem a idade e o sentimento de fazer o desenho em uma palavra, e vemos surgir sentimentos distintos e contraditórios conectados à história de cada um com seu desenho em palavras como "saudade", "vergonha", "liberdade", "alegria", "tensão", entre outras.

O desenho da figura humana vai auxiliar a turma, individual e coletivamente a entender seu processo gráfico diante do Desenvolvimento Gráfico Infantil (DGI), objeto de estudo de muitos autores e estudiosos brasileiros e estrangeiros. Também realizamos a Oficina do Grafismo sob forma de reviver as primeiras etapas do grafismo da criança, o que ajuda sobremaneira e entender o pensamento cinestésico (GOLDBERG, 2013).

Para o estudo do DGI levo toda a bibliografia que venho coletando ao longo dos anos sobre o assunto e trabalho o conteúdo buscando contextualizar autores 


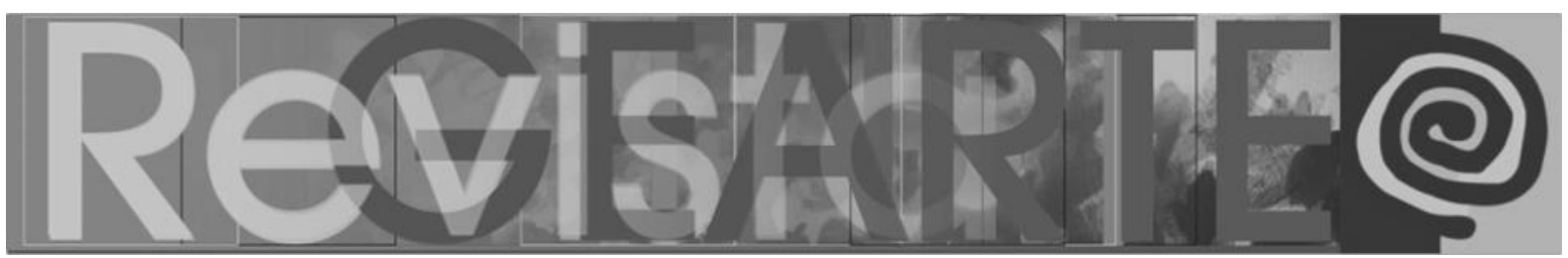

clássicos, porém bastante antigos, como Lowenfeld e Brittain (1970) com autoras contemporâneas como Derdyk (1989), Castell (2012), lavelberg (2008), Merèdieu (2004), Moreira (2009), entre outros. Estudamos um panorama do grafismo com base nas etapas descritas por Lowenfeld e Brittain (1970) - garatujas (desordenada, ordenada e nomeada), pré-esquema, esquema, realismo e pseudonaturalismo, dialogando com a leitura de Castell (2012) na descrição dos pensamentos cinestésico, imaginativo e simbólico. Costumo ilustrar com desenhos originais de crianças de hoje, assim como delas em processo criativo. Essas aprendizagens se ampliaram significativamente após minha pesquisa de doutorado sobre o que chamo de "autobiografismo" (GOLDBERG, 2016), em que tive a oportunidade de revisar e estudar mais profundamente o desenho infantil e seu potencial heurístico e formativo.

Após o estudo teórico solicito aos estudantes que façam um portfólio do desenho infantil, ilustrado com desenhos originais de crianças, jovens e adultos, buscando traçar uma linha do tempo gráfica na compreensão do processo de desenvolvimento plástico, suas principais aprendizagens e descobertas nos mais diversos níveis que compõem o desenvolvimento humano. O objetivo do portfólio é servir como um instrumento de consulta com subsídios teóricos e gráficos suficientes para entendimento da linguagem gráfica da criança capaz de disseminar informações essenciais junto à sociedade em geral, às escolas, pais etc.

O conhecimento é nossa arma diante da ignorância, e muitos equívocos são cometidos pela falta de conhecimento das pessoas. Portanto, cabe ao/à pedagogo/pedagoga esclarecer e ensinar sobre o desenho infantil em todas as suas instâncias de atuação, sob forma de valorizar as criações das crianças, disseminar sua importância, criar espaços de expressão e comunicação singular e espontâneas através da arte, defender e informar sobre os processos de desenvolvimento gráfico, a fim de que possam ser respeitados e estimulados por todos. É preciso também resgatar a autoconfiança criadora e criativa dos adultos ao mesmo tempo em que eles são peças fundamentais para auxiliar no processo de autoconfiança da criança diante de seu processo criativo, pois se os adultos

GOLDBERG, Luciane Germano. A aventura do "espalha-brasa”: arte na Pedagogia na Universidade Federal do Ceará. 454 Revista GEARTE, Porto Alegre, v. 8, n. 2, p. 434-458, maio/ago. 2021.

Disponível em: http://seer.ufrgs.br/gearte 


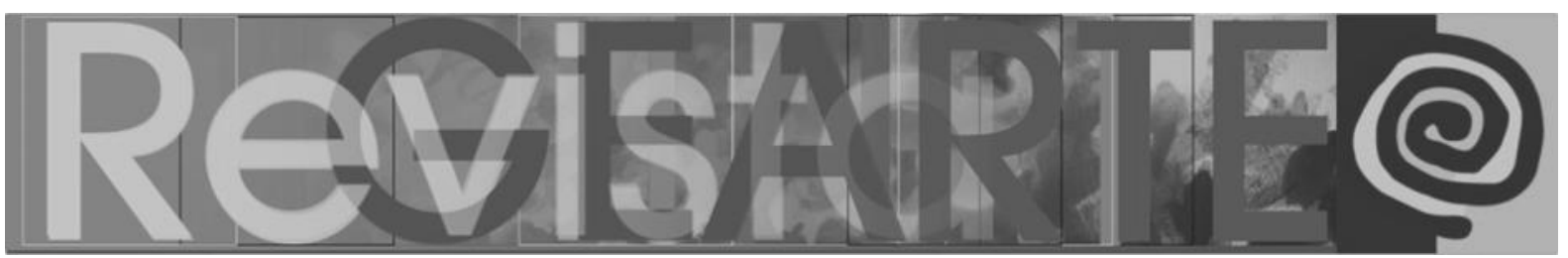

não acreditam nas capacidades das crianças, desencorajam toda e qualquer iniciativa que dê espaço para elas serem quem elas são, para que se expressem através de suas linguagens próprias e singulares.

\section{Por uma Pedagogia do "espalha-brasa"}

A título de considerações finais, externo aqui a alegria em poder participar desta obra sobre arte na Pedagogia, destacando a importância de valorizarmos os docentes deste campo dos cursos de Pedagogia e partilharmos metodologias, práticas e conteúdos com o público, acadêmico ou não. Nossa responsabilidade é plantar sementes em terreno fértil para que frutifiquem novos olhares, novas experiências, novas percepções e novas práticas pedagógicas que quebrem com a repetição e perpetuação do que temos visto ocupar o lugar da arte nas escolas. É preciso que os pedagogos e pedagogas tomem essa responsabilidade como ética e moral no respeito às linguagens infantis e estímulo das potencialidades expressivas da criança, em que a arte figura como potente ferramenta de construção de conhecimento sobre si e sobre o mundo.

Que possamos construir a arte na Pedagogia pela metáfora do "espalhabrasa", como uma aventura sensível e estética de produção de novas experiências, novos olhares, sensações, percepções e visões de mundo. Que possamos permitir o movimento, rodar e rodar até que nossas visões de mundo mudem, até que tenhamos diferentes perspectivas da realidade; que a aprendizagem tenha cor, luz, movimento, até alcançar a plenitude do céu azul infinito e saiamos transformados. Que ousemos permitir o voo individual e coletivo, dando asas à imaginação e à capacidade criadora, a partir do autoconhecimento e valorização da singularidade de cada um. Que não percamos jamais a esperança ainda que no meio de uma pandemia. Pelo amor à verdadeira educação, lutemos!

\section{Notas}

1 Dentre as múltiplas experiências formativas que vivi junto à Cleusa, vale destacar minha participação como voluntária e bolsista do Programa de Iniciação Científica (PIBIC) nos projetos "Utopias Concretizáveis Interculturais" e "Arte-Pré-Arte". O primeiro me encaminhou para o 


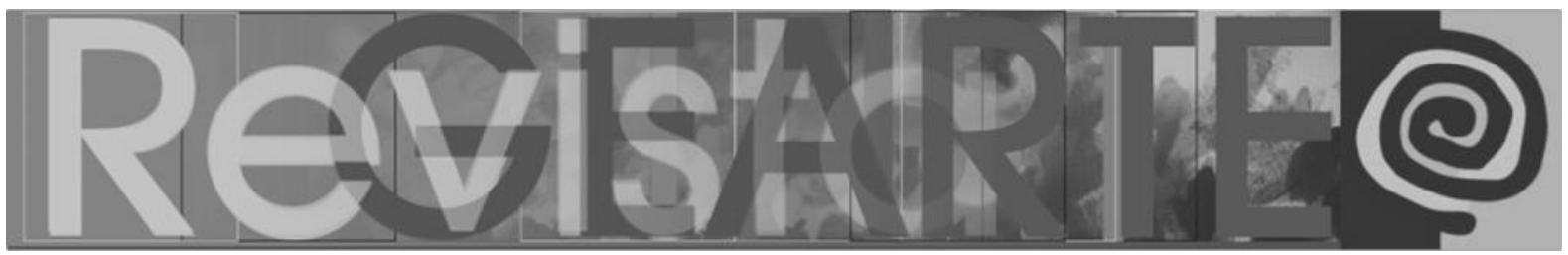

trabalho com arte-educação-ambiental que veio a colaborar para minha pesquisa de mestrado e o segundo, foi tema de minha monografia de conclusão de curso. Ambos contribuíram sobremaneira para as práticas artísticas e estéticas que desenvolvo hoje na arte na Pedagogia na UFC.

2 O Grupo de Pesquisa Arte na Pedagogia (GPAP), liderado pelas Professoras Miriam Celeste Martins (UPM) e Lucia Lombardi (UFSCar) vem, desde 2012, desenvolvendo pesquisas sobre o ensino de arte nos cursos de Pedagogia no país com importantes contribuições em eventos e publicações. Para saber mais: http://gpap-artenaPedagogia.blogspot.com/ e http://dgp.cnpq.br/dgp/espelhogrupo/7171489607866053.

3 O desenho infantil é tema da minha monografia de conclusão de curso em Educação Artística Artes Plásticas (GOLDBERG, 1999), dissertação de mestrado em Educação Ambiental (GOLDBERG, 2004) e tese de doutorado em Educação (GOLDBERG, 2016).

4 Para saber mais sobre a ação Linha do Tempo ver: "Narrativas de experiências formativas em arte: a linha do tempo de estudantes universitários" (GOLDBERG; OLINDA; BEZERRA, 2012); "Linha do tempo: Narrativas de vida e experiências formativas em arte" (GOLDBERG; BEZERRA, 2012); "Processos criativos em artes visuais: as experiências formativas de licenciandos da educação básica" (GOLDBERG e SALMITO, 2013); "Experiências formativas em arte dos licenciandos em Pedagogia da UFC: influências da pedagogia tecnicista" (GOLDBERG, 2014); "Do singular-plural e as experiências formativas em arte de licenciandos em Pedagogia na Universidade Federal do Ceará" (GOLDBERG; BEZERRA; PEREIRA JUNIOR, 2018).

5 Apresentamos uma comunicação sobre esta ação no CONFAEB de 2018, intitulada "Autorretrato: reflexões e reflexos de si na disciplina de arte e educação na UFC" (GOLDBERG; BEZERRA; PEREIRA JUNIOR, 2018). Para saber mais ver disciplina de Arte e Educação no Instagram @arteducufc.

6 Estas ações estão descritas com mais profundidade em "A importância do estudo do grafismo infantil para a formação do pedagogo na UFC" (GOLDBERG; ANDRADE, 2014), apresentado no III Encontro Internacional sobre Educação Artística e no Trabalho de Conclusão de Curso em Pedagogia: "A relevância do estudo do grafismo infantil no curso de Pedagogia da Faced - UFC" (ANDRADE, 2014).

\section{Referências}

ALVES, Rubens. Conversas sobre educação. Campinas, São Paulo: Verus, 2003.

ANDRADE, Ana Caroline Sales. A relevância do estudo do grafismo infantil no curso de Pedagogia da FACED - UFC, Orientador: Luciane Germano Goldberg. 2014. Trabalho de Conclusão de Curso. (Graduação em Pedagogia) - Universidade Federal do Ceará, Fortaleza, 2014.

BARBOSA, Ana Mae. Arte-educação no Brasil. 5. ed. São Paulo: Perspectiva, 2002.

BARBOSA, Ana Mae. A imagem no ensino da arte: anos 1980 e novos tempos. 8. ed. São Paulo: Perspectiva, 2010.

CASTELL, Cleusa Peralta. Pela linha do tempo do desenho infantil: um caminho trans estético para o currículo integrado. Rio Grande: FURG, 2012.

DERDYK, Edith. Formas de pensar o desenho: desenvolvimento do grafismo infantil. São Paulo: Scipione, 1989.

DERDYK, Edith. Papel em branco In: PINAZZA, Mônica Appezzato; COBI, Marcia Aparecida (Orgs.). Infância e suas linguagens. São Paulo: Cortez, 2014, p. 21-44.

DUARTE JÚNIOR, João Francisco. Fundamentos estéticos da educação. 7. ed. Campinas: Papirus, 2002.

GOLDBERG, Luciane Germano. A aventura do "espalha-brasa": arte na Pedagogia na Universidade Federal do Ceará. 456

Revista GEARTE, Porto Alegre, v. 8, n. 2, p. 434-458, maio/ago. 2021.

Disponível em: http://seer.ufrgs.br/gearte 


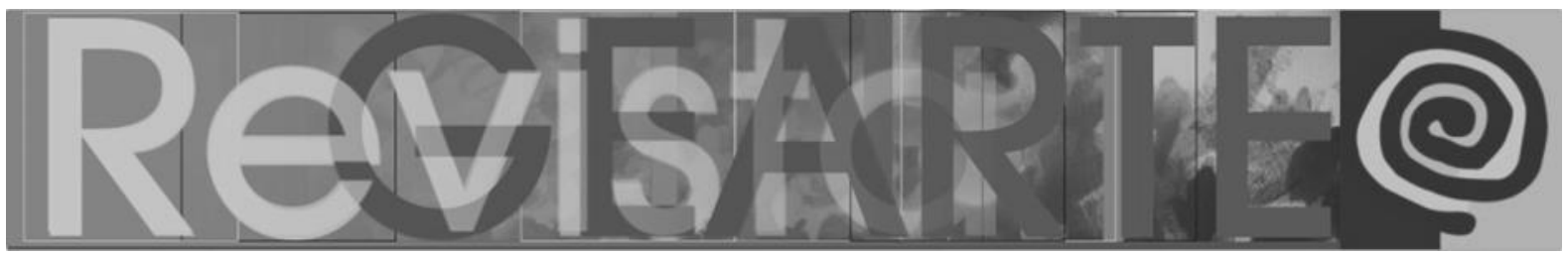

EISNER, Elliot. O que pode a educação aprender das artes sobre a prática da educação? Currículo sem Fronteiras, v. 8, n. 2, p. 5-17, jul./dez. 2008. Disponível em: http://www.curriculosemfronteiras. org/vol8iss2articles/eisner.pdf. Acesso em: 11 abr. 2021.

FERRAROTTI, Franco. História e histórias de vida: o método biográfico nas Ciências Sociais. Trad. Carlos Eduardo Galvão e Maria da Conceição Passeggi. Natal, RN: EDUFRN, 2014.

FERRAZ, Maria Heloísa Corrêa de T.; FUSARI, Maria Felisminda de Rezende. Arte na educação escolar. São Paulo: Cortez, 1993.

FORQUIN, Jean-Claude. Educação artística: para quê? In: PORCHER, Louis. Educação Artística: luxo ou necessidade? Tradução: Yan Michalski. São Paulo: Summus, 1973, p. 25-48.

GOLDBERG, Luciane Germano. Arte-Pré-Arte: um estudo acerca da retomada da expressão gráfica do adulto. Monografia (Graduação em Educação Artística-Licenciatura Plena) — Fundação Universidade Federal do Rio Grande, 1999.

GOLDBERG, Luciane Germano. Arte-Educação-Ambiental: o despertar da consciência estética e a formação de um imaginário ambiental na perspectiva de uma ONG. Dissertação (Mestrado em Educação Ambiental) - Pós-graduação em Educação Ambiental, Fundação Universidade Federal do Rio Grande, 2004.

GOLDBERG, Luciane Germano. Arte-Pré-Arte: memórias, metodologias, desdobramentos e implicâncias de uma vivência-formação. In: MEIRA, Mirela Ribeiro; SILVA, Ursula Rosa da; CASTELL, Cleusa Peralta. (Orgs.). Transprofessoralidades: sobre metodologias do ensino da arte. Pelotas: Editora UFPel, 2013, p. 87-101.

GOLDBERG, Luciane Germano. Experiências formativas em arte dos licenciandos em Pedagogia da UFC: influências da pedagogia tecnicista. In: ANDRADE, Francisco Ari de; VIANA, Carlos Augusto; JESUÍNO, Filipe de Menezes; SILVA, Renata Aquino da. (Orgs.). Educação Brasileira: conceitos e contextos. Fortaleza: Expressão Gráfica e Editora, 2014.

GOLDBERG, Luciane Germano. Autobiografismo: biografização e desenho infantil com crianças em acolhimento institucional. 2016. Tese (Doutorado em Educação) - Faculdade de Educação, Universidade Federal do Ceará, 2016.

GOLDBERG, Luciane Germano; OLINDA, Ercília Maria Braga de; BEZERRA, Larissa Rogério. Narrativas de experiências formativas em arte: a linha do tempo de estudantes universitários. In: CONGRESSO INTERNACIONAL DE PESQUISA (AUTO) BIOGRÁFICA - CIPA. V. Anais... PUC, Casa Leiria, Porto Alegre, 2012.

GOLDBERG, Luciane Germano; BEZERRA, Larissa Rogério. Linha do tempo: Narrativas de vida e experiências formativas em arte. In: CONGRESSO NACIONAL DA FEDERAÇÃO DOS ARTEEDUCADORES DO BRASIL - ARTE/EDUCAÇÃO: CORPOS EM TRÂNSITO. 22. Anais... São Paulo, 2012.

GOLDBERG, Luciane Germano; SALMITO, Ricardo Rigaud. Processos criativos em artes visuais: as experiências formativas de licenciandos da educação básica. In: DIÁLOGOS INTERNACIONAIS EM ARTES VISUAIS. 2. Anais... Recife, 2013.

GOLDBERG, Luciane Germano; ANDRADE, Ana Caroline Sales. A importância do estudo do grafismo infantil para a formação do pedagogo na UFC. ENCONTRO INTERNACIONAL SOBRE EDUCAÇÃO ARTÍSTICA. 3. Universidade Regional do Cariri - URCA, Juazeiro do Norte, 2014.

GOLDBERG, Luciane Germano. BEZERRA, Larissa Rogério; PEREIRA JÚNIOR, Leandro da Silva. Autorretrato: reflexões e reflexos de si na disciplina de Arte e Educação na UFC. In: GUIMARÃES, Leda; REGO, Luzirene (Orgs.). Ações políticas de/para enfrentamentos, resistências e recriações. In: CONGRESSO NACIONAL DA FEDERAÇÃO DE ARTE/EDUCADORES DO BRASIL. 28. Anais... Brasília, DF, 2018. ISSN 2525-880X.

GOLDBERG, Luciane Germano. BEZERRA, Larissa Rogério; PEREIRA JÚNIOR, Leandro da Silva. Do singular-plural e as experiências formativas em arte de licenciandos em Pedagogia na

GOLDBERG, Luciane Germano. A aventura do "espalha-brasa”: arte na Pedagogia na Universidade Federal do Ceará. 457 Revista GEARTE, Porto Alegre, v. 8, n. 2, p. 434-458, maio/ago. 2021.

Disponível em: http://seer.ufrgs.br/gearte 


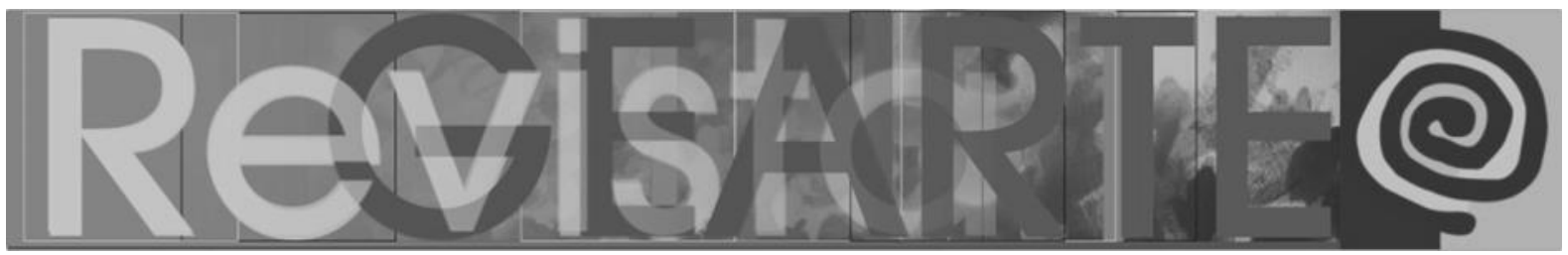

Universidade Federal do Ceará. In: CONGRESSO INTERNACIONAL DE PESQUISA (AUTO)BIOGRÁFICA - UNICID. 8. Anais... São Paulo, set. 2018. ISSN 2178-0676.

IAVELBERG, Rosa. O desenho cultivado da criança: prática e formação de professores. 2. ed. Porto Alegre: Zouk, 2008.

LOWENFELD, Viktor; BRITTAIN, William Lambert. Desenvolvimento da capacidade criadora. São Paulo: Mestre Jou, 1970.

MARTINS, Mirian Celeste; LOMBARDI, Lucia Maria Salgado dos Santos. A arte na Pedagogia e a formação do professor para a Educação Infantil e anos iniciais: inquietações e esperanças. Trama Interdisciplinar, São Paulo, v. 6, n. 2, p. 23-36, maio/ago. 2015.

MÈREDIEU, Florence de. O desenho infantil. 14. ed. São Paulo: Cultrix, 2004.

MOREIRA, Ana Angélica Albano. O espaço do desenho: a educação do educador. 13. ed. São Paulo: Loyola, 2009.

PASSEGGI, Maria da Conceição. Prefácio. In: DELORY-MOMBERGER, Christine. Biografia e Educação: Figuras do indivíduo-projeto. Natal, Brasil: EDUFRN; São Paulo: Paulus, 2008. (pp. 1320).

READ, Herbert. A educação pela arte. São Paulo: Martins Fontes, 2001.

SANTOS, Boaventura de Sousa. Um discurso sobre as ciências. 5. ed. São Paulo: Cortez, 2008.

SILVA, Everson Melquiades Araújo; ARAÚJO, Clarissa Martins de. Tendências e concepções do ensino de arte na educação escolar brasileira: um estudo a partir da trajetória histórica e socioepistemológica da arte/educação. In: REUNIÃO DA ANPED, 30., 2007. Anais... Rio de Janeiro: ANPED, 2007. Disponível em: http://www.anped.org.br/reunioes/30ra/grupo_e studos/ge01-3073--int.pdf. Acesso em: 11 abr. 2021.

\section{Luciane Germano Goldberg}

Professora do Departamento de Educação e do Programa de Mestrado Profissional da Universidade Federal do Ceará. Licenciada em Artes Plásticas. Mestre em Educação Ambiental pela Universidade Federal de Rio Grande/RS. Doutora em Educação Brasileira pela Universidade Federal do Ceará. Líder do Grupo de Pesquisa Dialogicidade, Formação Humana e Narrativas.

ORCID: https://orcid.org/0000-0002-4140-3864

E-mail: lugoldberg@hotmail.com

Currículo: http://lattes.cnpq.br/9917247618926283

Recebido em 21 de fevereiro de 2021 Aceito em 29 de abril de 2021 